\title{
Fermentabilitas Rumen dan Kecernaan In Vitro Ransum yang Disuplementasi Kulit Buah Kopi Produk Fermentasi Jamur Pleurotus ostreatus
}

\author{
Rumen Fermentability and In Vitro Digestibility of Diet Supplemented with Coffee Husk \\ Fermented by Pleurotus ostreatus Mushroom
}

\author{
Irma Badarina ${ }^{1}$, Dwierra Evvyernie ${ }^{2}$, Toto Toharmat ${ }^{2}$, Elis Nina Herliyana ${ }^{3}$ \\ ${ }^{1}$ Jurusan Peternakan Fakultas Pertanian Universitas Bengkulu \\ Jalan Raya WR Supratman Kodya Bengkulu \\ Email : ibadarina@yahoo.com \\ ${ }^{2}$ Departemen Ilmu Nutrisi dan Teknologi Pakan,Fakultas Peternakan IPB \\ ${ }^{3}$ Departemen Silvikultur, Fakultas Kehutanan IPB
}

\begin{abstract}
The aim of this research was to evaluate the potency of coffee husk fermented with Pleurotus ostreatus as feed supplement in vitro through rumen fermentability and in vitro digestibility (dry matter and organic matter). Fermented coffee husk were incorpotared into concentrate diet as much as 0\% (R0), 2\% (R2), 4\% (R4) and 6\% (R6) from total dry matter in diet. The completely blok design was used with three sources of rumen goat innoculum as block and the level of coffee husk supplementation as treatment. The research showed that there were no significant effects on rumen $\mathrm{pH}$ and $\mathrm{NH}_{3}-\mathrm{N}$. The mean of rumen $\mathrm{pH}$ was in normal range. Supplementation for up to the $6 \%$ did not interfere rumen protein metabolism. Volatile fatty acid (VFA) concentration significantly decreased with coffee husk than control diet, and there was no significant difference in VFA production among supplemented diets. The VFA productions were in normal range. There was no significant difference in rumen microbia population (protozoa and bacteria). This condition suggested that the supplementation of fermented coffee husk for up to $6 \%$ was not endangering the rumen microbia. The dry matter and organic matter were decreased with coffee husk. The supplementation of coffee husk for up to $6 \%$ in the diet was still showing good digestion.
\end{abstract}

Key Words : Coffee husk, P.ostreatus, fermentability, digestibility, rumen

\begin{abstract}
ABSTRAK
Penelitian ini bertujuan mengevaluasi potensi kulit buah kopi yang telah difermentasi jamur Pleurotus ostreatussebagai pakan suplemen secara in vitro berupa tingkat fermentabilitas dalam rumen dan kecernaan bahan kering serta bahan organik ransum. Kulit buah kopi produk biokonversi ditambahkan ke dalam ransum konsentrat sebanyak $0 \%(\mathrm{R} 0), 2 \%(\mathrm{R} 2)$, 4\%(R4) dan 6\%(R6) dari total bahan kering ransum. Rancangan penelitian menggunakan rancangan acak kelompok dan tiga sumber cairan rumen kambing sebagai blok dan level pemakaian kulit buah kopi dalam ransum sebagai perlakuan. Hasil penelitian menunjukkan bahwa perlakuan tidak memberikan pengaruh yang nyata terhadap $\mathrm{pH}$ rumen dan $\mathrm{NH}_{3}-\mathrm{N}$. Nilai rerata $\mathrm{pH}$ rumen dalam penelitian ini berada dalam kisaran normal. Suplementasi sampai level tertinggi (6\%) tidak mengganggu metabolisme protein dalam rumen. Kadar VFA nyata menurun pada ransum yang disuplementasi dibandingkan ransum kontrol, dan tidak terdapat perbedaan yang nyata dalam produksi VFA diantara ransum yang disuplementasi. Produksi VFA berada dalam kisaran normal. Perlakuan tidak memberikan pengaruh nyata terhadap populasi mikrobia rumen (protozoa dan bakteri). Hal ini memberikan indikasi bahwa suplementasi kulit buah kopi produk biokonversi sampai level 6\% tidak membahayakan kehidupan mikroba rumen. Kecernaan bahan kering dan bahan organik ransum yang disuplementasi menurun dibandingkan ransum kontrol. Level $6 \%$ penambahan di dalam ransum, kecernaan masih dikategorikan baik.
\end{abstract}

Kata Kunci : Kulit buah kopi, P.ostreatus, fermentabilitas, kecernaan, rumen

\section{PENDAHULUAN}

Kopi merupakan salah satu komoditi pertanian yang cukup penting di
Indonesia. Buah kopi umumnya diproses melalui metoda kering dan hanya sebagian kecil melalui metoda basah. Kulit buah kopi (coffee husk) diperoleh setelah biji 
kopi segar dikeringkan dan digiling. Kulit buah kopi tersedia dalam jumlah yang besar, sekitar $21.5 \%$ dari berat total buah kopi (Muryanto et al. 2009). Saat ini keberadaan kulit buah kopi masih merupakan limbah pertanian. Sejumlah besar limbah kulit kopi menumpuk di tempat pengolahannya. Upaya yang biasa dilakukan untuk mengenyahkan limbah tersebut yaitu dengan dibakar atau dibuang ke sungai. Hanya sebagian kecil dikembalikan ke lahan sebagai pupuk. Kondisi ini dikhawatirkan akan menimbulkan masalah polusi lingkungan.

Kulit buah kopi berpotensi sebagai salah satu sumber bahan pakan ruminansia. Kadar proteinnya adalah 9.2-11.3\% (Fan dan Soccol 2005). Komponen dinding selnya dapat digunakan oleh ruminansia sebagai sumber energi (Russel et al. 2009). Bagaimanapun kadar lignin yang tinggi membatasi kecernaan selulosa dan hemiselulosa. Kulit buah kopi mengandung substansi anti nutrisi seperti kafein, tannin, lignin dan senyawa polifenol (Orozco et al. 2008). Adanya tannin dan kafein menurunkan kesukaan dan palatabilitasnya bagi ternak (Mazzafera 2002).

Penerapan bioteknologi adalah pertimbangan yang tepat untuk memperbaiki nilai nutrisi limbah pertanian. Kulit buah kopi kaya akan bahan organik, dan cocok sebagai substrat untuk proses kultivasi. Jamur kelas tinggi diketahui memiliki kemampuan untuk mengubah secara biologis limbah pertanian menjadi produk bernilai tambah melalui aktivitas enzim ekstraselular. Salah satu jamur yang termasuk kelompok ini adalah Pleurotus ostreatus (jamur tiram). Jamur $P$. ostreatus dapat ditanam pada berbagai jenis substrat lignoselulosa seperti jerami gandum, bagas tebu dan kulit buah coklat (Fazaeli et al. 2004; Okano et al. 2007; Alemawor 2009). Jamur $P$. ostreatus tergolong white rot fungi yang mampu mendegradasi lignin karena memproduksi enzim ligninolitik ekstraselular seperti laccase, lignin peroxidase dan Mn peroxidase (Periasamy dan Natarajan 2004; Mayer dan Staples 2002).

Kemampuan $\quad P$. ostreatus mendegradasi sejumlah besar jenis substrat lignoselulosa, menyebabkan jamur ini berperan penting dalam menangani limbah organik. Spesies Pleurotus telah digunakan oleh manusia karena nilai nutrisinya, mengandung bahan-bahan obat, mengubah limbah menjadi pakan ternak dan pengaruh-pengaruh menguntungkan lainnya (Ijeh et al. 2009; Gregori et al. 2007; Darwish et al. 2012). Produk biokonversi dari jamur P.ostreatusdapat digunakan sebagai makanan kesehatan (suplemen).

Jamur P.ostreatus tidak hanya diketahui mampu sebagai dekomposer primer bahan lignoselulosa, namun juga telah lama dikenal sebagai makanan suplemen. P.ostreatus mengandung sejumlah senyawa-senyawa aktif secara biologis membantu meningkatkan kesehatan; berpotensi membantu melawan penyakit (Wong et al. 2011; Patel et al. 2012). Komponen senyawa aktif ini bernama $\beta$-glucan merupakan salah satu polimer struktural dinding sel (Chan et al. 2009). Komponen bioaktif lain yang 
berperan sebagai anti mikrobial berasal dari metabolit sekunder yang dihasilkan sebagai senjata pertahanan diri jamur dari lingkungan sekitar. Metabolit sekunder ini antara lain triterpenoid, alkaloid dan flavonoid (Ijeh et al., 2009).

Penelitian ini bertujuan untuk mengevaluasi potensi kulit buah kopi yang telah difermentasi oleh jamur P.ostreatus (jamur tiram) sebagai pakan suplemen ternak ruminansia melalui peubah fermentabilitas rumen dan kecernaan ransum in vitro.

\section{BAHAN DAN METODA}

\section{Kultivasi Kulit Buah Kopi dengan P.ostreatus}

Kulit buah kopi diambil dari tempat penggilingan biji kopi di kabupaten Rejang Lebong Provinsi Bengkulu yang merupakan salah satu penghasil kopi terbesar di pulau Sumatera.Kulit kopi yang dipilih baru dihasilkan dari penggilingan kopi.

Kulit buah kopi dikeringkan sehingga mencapai kadar air 10-15\%. Percobaan inokulasi dilakukan pada skala laboratorium. Metoda dan komposisi subtrat mengadopsi tehnik Herliyana et al. (2008). Komposisi subtrat terdiri atas $82.5 \%$ kulit buah kopi, $15 \%$ dedak padi, $1.5 \%$ gips dan $1.0 \% \mathrm{CaCO}_{3}$. Air bersih ditambahkan sebanyak $65-70 \%(\mathrm{v} / \mathrm{w})$. Semua bahan dicampurkan dan dikomposkan selama 24 jam. Sebanyak 400 gram campuran dimasukkan ke dalam kantong propilene. Kantong diikat bagian ujungnya dengan memasukkan kapas ke dalam cincin. Kantong disterilkan pada suhu $121^{\circ} \mathrm{C}$ selama 30 menit. Setelah dingin, masing-masing kantong diinokulasi dengan \pm 15 gram $(3.75 \%)$ bibit. Kantong yang telah diinolukasi bibit jamur kemudian ditempatkan dalam ruang inkubasi pada suhu $22-28{ }^{\circ} \mathrm{C}$ dan kelembaban relatif $60-80 \%$ selama 60 hari perioda inkubasi.

Baglog substrat yang telah penuh dikolonisasi oleh miselium jamur P.ostreatus dibuka dan substrat dikeringkan dalam oven $60^{\circ} \mathrm{C}$ selama 2 hari kemudian dihaluskan. Kulit buah kopi yang telah difermentasi siap digunakan lebih lanjut.

\section{Ransum Perlakuan dan Rancangan Percobaan}

Potensi kulit buah kopi produk biokonversi sebagai pakan suplemen dievaluasi dengan menambahkannya ke dalam ransum konsentrat sebanyak 0\%(R0), 2\%(R2), 4\%(R4) dan 6\%(R6) dari total bahan kering ransum. Ransum disusun untuk memenuhi kebutuhan nutrisi kambing perah laktasi dengan protein kasar 11-12\% dan TDN 55\% (NRC 2001) yang terdiri dari rumput gajah $(60 \%)$ dan konsentrat $(40 \%)$. Ransum konsentrat disusun dari ampas kedele $(34.88 \%)$, dedak padi (23.26\%), bungkil kelapa (23.26\%), onggok (11.63\%) dan crude palm oil (CPO) $(6.96 \%)$. Komposisi zat makanan hijauan dan konsentrat yang digunakan untuk fermentasi in vitro dapat dilihat pada Tabel 1.

Penelitian menggunakan rancangan acak kelompok dan tiga sumber cairan rumen sebagai blok dan level pemakaian kulit buah kopi dalam ransum sebagai 
perlakuan. Percobaan dilakukan dengan dua ulangan. Hasil yang terbaik pada tahap ini akan digunakan untuk percobaan in vivo.

Tabel 1. Komposisi zat makanan hijauan dan konsentrat dalam percobaan in vitro

\begin{tabular}{lcc}
\hline Zat Makanan $(\%)$ & Rumput gajah & Konsentrat \\
\hline Bahan kering & 21.00 & 72.75 \\
Abu & 10.60 & 7.11 \\
Protein kasar & 9.60 & 13.39 \\
Serat kasar & 32.70 & 27.58 \\
Lemak kasar & 1.90 & 4.87 \\
Beta-N & 27.12 & 47.05 \\
\hline
\end{tabular}

Hasil Analisa Proksimat di Lab. Ilmu dan Teknologi Pakan IPB (2012)

\section{Karakteristik Fermentasi Rumen dan Kecernaan In vitro}

Karakteristik fermentasi $\quad(\mathrm{pH}$ rumen, konsentrasi $\mathrm{NH}_{3}-\mathrm{N}$, totalvolatile fatty acid/ total VFA), populasi mikroba rumen (protozoa dan bakteri rumen), kecernaan bahan kering dan bahan organik in vitro dianalisis untuk mengevaluasi nilai nutrisinya sebagai suplemen pakan. Kadar ammonia-N dianalisis dengan metoda mikrodifusi Conway (Obrink 1954). VFA total dianalisis dengan metoda distilasi uap. Kecernaan bahan kering (KBK) dan kecernaan bahan organik $(\mathrm{KBO})$ in vitro dievaluasi menurut metoda Tilley dan Terry (1963).

Cairan rumen berasal dari rumen kambing diambil dari tempat pemotongan kambing didaerah Empang Bogor. Pengambilan cairan rumen dilakukan dengan mengambil isi rumen kemudian dimasukkan dalam termos yang sebelumnya berisi air panas namun air panas segera dibuang ketika isi rumen akan dimasukkan ke dalam termos. Di laboratorium, selanjutnya isi rumen diperas dan cairan disaring dengan menggunakan kain kasa. Hasil saringan dimasukkan ke dalam termos yang sebelumnya diisi air hangat (air hangat dibuang ketika cairan rumen dimasukkan dalam termos) dan terus dialiri $\mathrm{CO}_{2}$. Seterusnya cairan rumen segera digunakan.

\section{Analisis Populasi Protozoa Rumen}

Perhitungan populasi protozoa menggunakan $0.5 \mathrm{ml}$ larutan fiksasi (Methyl green formaline saline/MFS) yang dimasukkan ke dalam tabung reaksi dan dicampur dengan cairan rumen $0.5 \mathrm{ml}$ kemudian diaduk hingga merata (Ogimoto dan Imai, 1981). Sebanyak $0.1 \mathrm{ml}$ sampel diteteskan dengan menggunakan pipet pada bilik hitung (hemacytometer) dan ditutup dengan covered glass. Penghitungan protozoa dilakukan dengan bantuan mikroskop dengan menggunakan perbesaran 40x. Dari jumlah protozoa yang didapatkan dengan prosedur penghitungan ini, maka jumlah protozoa yang dikandung per $1 \mathrm{ml}$ cairan rumen dapat dihitung dengan rumus sebagai berikut:

Populasi Protozoa/mL $=(1 / 0.1 \times 0.065 \times$ $5 \times 16) \times n \times d$

Dimana $: \mathrm{n}=$ jumlah protozoa pada counting chamber

$$
\mathrm{d}=\text { pengenceran sampel }
$$




\section{Analisis Populasi Bakteri Rumen}

Populasi bakteri dihitung dengan metode pencacahan koloni bakteri hidup. Prinsip kerjanya adalah cairan rumen diencerkan secara serial, lalu disimpan dalam tabung Hungate. Media tumbuh yang digunakan untuk menghitung populasi bakteri total adalah BHI (Brain Heart Infusion). Pembuatan media BHI yaitu dengan cara mencampurkan bahanbahan seperti BHI powder $3.7 \mathrm{~g}$, glukosa $0.05 \mathrm{~g}$, selulobiosa $0.05 \mathrm{~g}$, pati $0.05 \mathrm{~g}$, cystein 0.05 , hemin $100 \mu$, resazurin 0.005 $\mathrm{g}$ dan agar $1.5 \mathrm{~g}$. Semua bahan dimasukkan kedalam botol steril. Campuran bahan-bahan ini dipanaskan sampai terjadi perubahan warna dari coklat kekuningan menjadi coklat kemerahan dan berubah kembali menjadi coklat kekuningan. Setelah itu larutan didinginkan dan dialiri gas $\mathrm{CO}_{2}$. Media $\mathrm{BHI}$ anaerob dimasukkan ke dalam tabung hungate yang sebelumnya telah diisi bacto agar sebanyak $0.150 \mathrm{~g}$ dengan volume masing-masing $4.9 \mathrm{ml}$.

Sampel cairan rumen yang telah mengalami perlakuan dan difermentasi empat jam dipipet $0.05 \mathrm{ml}$ dan dimasukkan ke dalam media pengencer. Pengenceran dilakukan sebagai berikut: $0.05 \mathrm{ml}$ kultur bakteri dimasukkan de dalam $4.95 \mathrm{ml}$ media pengencer. Selanjutnya dari media pengencer diambil kembali sebanyak 0.05 $\mathrm{ml}$ lalu dimasukkan ke dalam $4.95 \mathrm{ml}$ media pengencer berikutnya sehingga terdapat pengenceran $10^{-1}, 10^{-2}, 10^{-3}$ dan $10^{-4}$. Dari masing-masing seri tabung pengenceran diambil sebanyak $0.1 \mathrm{ml}$, kemudian dimasukkan ke media agar dan diputar sambil dialiri air pada roller,sehingga media agar dapat menjadi padat secara merata. Selanjutnya bakteri diinkubasi selama 24 jam. Koloni bakteri dihitung pada setiap tabung menggunakan marker.

Jumlah koloni

$$
\text { Populasi bakteri }=\frac{}{0.05 \times 10^{-\mathrm{x}} \times 0.1}
$$

Keterangan : $\mathrm{x}=$ tabung seri pengenceran ke-x

Data dianalisis keragamannya dengan ANOVA (Steel dan Torrie 2003). Apabila terdapat perbedaan yang significant antar perlakuan dilakukan uji lanjut menggunakan Duncan Multiple Range Test. Perbedaan antar perlakuan dinyatakan pada taraf $\mathrm{p}<0.05$.

\section{HASIL DAN PEMBAHASAN}

Tabel 2. Menunjukkan fermentabilitas $\left(\mathrm{pH}, \mathrm{NH}_{3}-\mathrm{N}\right.$ dan produksi VFA), populasi mikrobia rumen, kecernaan bahan kering dan bahan organik ransum yang disuplementasi kulit buah kopi produk biokonversi. Perlakuan tidak memberikan pengaruh yang nyata terhadap $\mathrm{pH}$ rumen $(\mathrm{p}>0.05)$ dan $\mathrm{NH} 3-\mathrm{N}(\mathrm{p}>0.05)$. Nilai rerata $\mathrm{pH}$ rumen dalam penelitian ini berada dalam kisaran normal. Hal ini sebagaimana yang telah dilaporkan oleh Sung et al. (2007) bahwa pH ideal rumen untuk mempertahankan proses metabolisme normal rumen adalah 6.0-7.0. Kecernaan serat kasar menurun pada $\mathrm{pH}$ yang rendah, khususnya dibawah pH 6.0.

Peningkatan level suplementasi kulit buah kopi produk biokonversi tidak menimbulkan perbedaan yang nyata 
terhadap level $\mathrm{NH}_{3}-\mathrm{N}$ rumen. Kondisi ini menunjukkan bahwa suplementasi sampai level tertinggi (6\%) tidak mengganggu metabolisme protein dalam rumen. Kadar VFA menurun pada ransum yang mengandung kulit buah kopi produk biokonversi $\quad(\mathrm{p}<0.05) \quad$ dibandingkan ransum kontrol (tanpa suplementasi kulit buah kopi produk biokonversi), dan tidak terdapat perbedaan yang nyata dalam produksi VFA diantara ransum R2, R4 dan R6. Menurunnya produksi VFA seiring dengan meningkatnya level kulit buah kopi produk biokonversi dalam ransum kemungkinan karena masih tingginya kadar lignin sehingga tidak dapat didegradasi dengan baik oleh mikroba rumen. Badarina et al. (2013) melaporkan bahwa terjadi penurunan kadar lignin kulit buah kopi setelah difermentasi sebesar $31.12 \%$, namun nilai lignin kulit buah kopi masih cukup tinggi yaitu berkisar $45.04 \%$. Hasil penelitian ini didukung oleh $\mathrm{Xu}$ et al. (2007) yang melaporkan bahwa cairan rumen dari sapi pejantan Holstein atau domba yang mendapat pakan limbah ampas kopi mengandung konsentrasi total VFA nyata lebih rendah daripada kelompok ternak yang tidak disuplementasi ampas kopi. $\quad$ Kadar $\mathrm{NH}_{3-}$ $\mathrm{N}$ dan produksi VFA dalam penelitian ini berada dalam kisaran normal. Sutardi (1977) menyatakan bahwa kisaran produksi NH3 dan VFA yang baik untuk kehidupan mikroba rumen adalah 4-12 milimol $\mathrm{NH}_{3}$ dan 80-160 milimol VFA.

Tabel 2. Produksi $\mathrm{pH}, \mathrm{N}-\mathrm{NH}_{3}$, VFA, kecernaan bahan kering dan bahan organik ransum yang ditambahkan produk biokonversi

\begin{tabular}{|c|c|c|c|c|c|}
\hline Parameter & R0 & $\mathrm{R} 2$ & $\mathrm{R} 4$ & R6 & Pvalue \\
\hline $\mathrm{pH}$ & $6.77 \pm 0.005$ & $6.78 \pm 0.005$ & $6.80 \pm 0.04$ & $6.77 \pm 0.008$ & 0.43 \\
\hline N-ammonia (mM) & $12.32 \pm 1.91$ & $12.38 \pm 1.83$ & $13.19 \pm 0.00$ & $11.88 \pm 1.091$ & 0.62 \\
\hline VFA (mmol/liter) & $173.79 \pm 8.66^{\mathrm{a}}$ & $150.62 \pm 0.094^{\mathrm{b}}$ & $142.73 \pm 10.91^{\mathrm{b}}$ & $138.71 \pm 9.44^{\mathrm{b}}$ & 0.031 \\
\hline $\begin{array}{l}\text { Protozoa,cell/mL } \\
(\log 10)\end{array}$ & $5.71 \pm 0.086$ & $5.73 \pm 0.17$ & $5.69 \pm 0.27$ & $5.73 \pm 0.16$ & 0.99 \\
\hline Bakteri $\left(\log 10^{9}\right)$ & $9.67 \pm 0.47$ & $9.00 \pm 0.82$ & $9.33 \pm 0.47$ & $9.33 \pm 0.47$ & 0.71 \\
\hline $\begin{array}{l}\text { Kecernaan Bahan } \\
\text { Kering }(\%)\end{array}$ & $70.48 \pm 2.13^{\mathrm{a}}$ & $68.94 \pm 1.94^{\mathrm{ab}}$ & $65.59 \pm 0.16^{\mathrm{c}}$ & $66.63 \pm 0.29^{b c}$ & 0.029 \\
\hline $\begin{array}{l}\text { Kecernaan bahan } \\
\operatorname{organik}(\%)\end{array}$ & $70.34 \pm 1.83^{\mathrm{a}}$ & $68.88 \pm 1.75^{\mathrm{a}}$ & $64.74 \pm 1.15^{b}$ & $66.42 \pm 0.73^{\mathrm{ab}}$ & 0.044 \\
\hline
\end{tabular}

Catatan: Superskrip yang berbeda yang baris yang sama menunjukkan perbedaan pada taraf $(\mathrm{p}<0.05)$. Level pemakaian kulit buah kopi fermentasi sebagai suplemen pakan di dalam ransum: R0(kontrol/tanpa kulit buah kopi fermentasi), $\mathrm{R} 2(2 \%$ dalam ransum), R4(4\% dalam ransum) dan $\mathrm{R} 6$ (6\% dalam ransum).

Perlakuan tidak memberikan pengaruh nyata terhadap populasi mikrobia rumen (protozoa dan bakteri) ( $P>0.05)$ ( Tabel 2.). Hal ini memberikan indikasi bahwa suplementasi kulit buah kopi produk biokonversi sampai level $6 \%$ dari total bahan kering ransum tidak membahayakan kehidupan mikroba rumen. Pemakaian kulit buah kopi produk biokonversi didalam ransum menurunkan kecernaan bahan kering dan bahan organik dibandingkan ransum kontrol/tanpa kulit buah kopi yang telah dikultivasi $(\mathrm{p}<0.05)$.

Inkorporasi sampai dengan level $6 \%$ di dalam ransum memiliki nilai kecernaan lebih dari 55\%, nilai dimana lebih tinggi dari nilai minimal kecernaan yang dianjurkan (55\%) untuk hijauan tropika yang berkualitas rendah (Preston dan Leng 1987). Level 6\% (R6) 
penambahan di dalam ransum, kecernaan masih dikategorikan baik.

\section{SIMPULAN}

Pemanfaatan kulit buah kopi produk biokonversi tidak menimbulkan perbedaan didalam $\mathrm{pH}$ rumen dan produksi $\mathrm{N}$-ammonia tetapi menurunkan produksi VFA dan kecernaan (bahan kering dan bahan organik). Penambahan kulit buah kopi produk biokonversi sampai level 6\% tidak mempengaruhi populasi mikrobia rumen. Penambahan kulit buah kopi produk biokonversi dalam ransum sampai level 6\% masih dapat diterapkan karena kecernaan masih dikategorikan baik.

\section{UCAPAN TERIMAKASIH}

Peneliti mengucapkan terimakasih kepada DP2M Dikti yang telah memberikan dana penelitian melalui kegiatan Hibah Bersaing dengan Surat Perjanjian No. 256/h30.10/p1/2011 tanggal 20 April 2011.

\section{DAFTAR PUSTAKA}

Alemawor, F., V. P.Dzogbefia, E.O.K. Oddoye, and J.H.Oldham.2009. Effect of Pleurotus ostreatus fermentation on cocoa pod husk composition: influence of fermentation period and $\mathrm{Mn}^{++}$supplementation on the fermentation process. African Journal of Biotechnology. 8 (9) : 1950-1958.
Badarina, I., D. Evvyernie, T.Toharmat, E.N.Herliyana, and L.K. Darusman. 2013. Nutritive value of coffee husk fermented with as ruminant feed. Med. Pet. 36 (1): 58-63.

Darwish, G.A.M.A., A.A. Bakr, \& M.M.F.Abdallah. 2012. Nutritional value upgrading of maize stalk by using Pleurotus ostreatus and Saccharomyces cerevisiae in solid state fermentation. Annals of Agricultural Science 57 (1): 47-51.

Fan, L and C. R. Soccol. 2005. Coffee residue. http://www. fungifun. org/mushworld/shiitake mush room cultivation mushroom growers handbooks 2 mushworld com chapter04 02-p.92.pdf. 26 Maret 2010

Fazaeli, H., H.Mahmodzadeh, A.Azizi, Z.A. Jelan, J.B. Liang, Y. Rouzbehan, and A.Osman. 2004. Nutritive value of wheat straw treated with Pleurotus fungi. Asian-Aust. J. Anim. Sci. 17 (12) :1681-1688.

Gregori, A., Mirjan Svagelj, and J. Pohleven. 2007. Cultivation technique and medicinal properties of Pleurotus spp. Review. Food Technol. Biotechnol.[26 February 2012].

Herliyana, E.N., D. Nandika, Achmad, L.I. Sudirman, and A.B. Witarto. 2008. Biodegradation of Sengon-wood Sawdust Substrate by Pleurotus Group Fungi from Bogor. J. 
Tropical Wood Science and Technology. Vol 6, No. 2.

Ijeh, I.I., A.I. Okwujiako, C.P. Nwosu, and H.I. Nodim. 2009. Phytochemical composition of Pleurotus tuber regium and effect of its dietary incorporation on body /organweights and serum triacylglycerols in albino mice. J. of Medicinal Plants Research 3:939-943.

Mayer AM and R.C. Staples. 2002. Laccase: new functions for an old enzyme. Phytochemistry 60:131565.

Mazzafera, P. 2002. Degradation of Caffeine by Microorganisms, and Potential Use of Decaffeinated Coffee Husk and Pulp in Animal Feeding. Scientia Agricola. Vol. 59. N.4 p. 815-821

Muryanto, U.Nuschati, D. Pramono dan T. Prasetyo. 2005. Potensi Limbah Kulit Kopi sebagai Pakan Ayam. http://peternakan.litbang.deptan.go. id/publikasi/lokakarya/lkugs0621.pdf

NRC. 2001. Nutrient Requirement of Dairy Cattle. Revised Ed. Washington DC: National Academy Press.

Okano, K., S. Fukui, R. Kitao, and T. Usagawa. 2007. Effect of cultural length of Pleurotus eryngii grown on sugarcane bagasse on in vitro digestibility and chemical composition. Anim. Feed. Sci. Technol . 136: 240-247.
Orozco, A.L., M.I. Perez, O. Guevara, J. Rodriguez., M. Hernandez, and Gonzales-Vila. 2008. Biotechnology enhancementof coffee pulp residues by solid state fermentation with streptomyces. Py-Gel MS Analysis. J. Anal. Appl. Pyrolysis 81:247-252.

Periasamy, K. and K. Natarajan. 2004. Role of lignocellulosic enzymes during basidiomata production by Pleurotus djamor var roseas. Indian Journal of Biotechnolog $3: 577-583$. Russel, J. B, R. E. Muck, and P. L. Weimer. 2009. Quantitative analysis of cellulose degradation and growth of cellulolytic bacteria in rumen. Minireview. FEMS Microbiol Ecol .67: 183-197.

Steel, R.G.D. \& J.H. Torrie. 2003. Principles and Procedures of Statistics. $2^{\text {ed }}$. Mc. Graw-Hill Book Co. Inc., New- York.

Sutardi, T. 1977. Ikhtisar Ruminologi. Bahan Penataran. Kursus Peternakan Sapi Perah di Kayu Ambon. Lembang. BPPLP-Ditjen Peternakan-FAO.

Tilley, J.M.A and R.A. Terry. 1963. A two stage technique for the in vivo digestion of forage crops. J. Brit. Grassland Soc. 18; 104.

Xu, C.C., Y. Cai, J.G. Zhang, and M. Ogawa. 2007. Fermentation quality and nutritive value of total mixed ration silage containing coffee ground at ten or twenty percent of dry matter. J. Anim. Sci. 85:10241029 